\title{
Some aspects of the limnology of Nguru lake, northeastern Nigeria
}

\author{
Mohammad Mustapha Abubakar ${ }^{1}$ and J. Yaji Abubakar ${ }^{2 *}$ \\ ${ }^{I}$ Department of Biological Sciences, Federal University Dutse, Nigeria \\ ${ }^{2}$ Department of Fisheries and Aquaculture, Adamawa State University, Mubi Nigeria \\ *Corresponding author E-mail: mmabubakar2005@yahoo.com
}

\begin{abstract}
Aspects of physico-chemical factors and zooplankton of Nguru Lake were studied for a period of twenty four months between May 2006 and April 2008. With the aim of acquiring the necessary knowledge for management of lakes in semi arid areas of Nigeria. Using standard methods. Nguru Lake, which is part of the Hadejia-Nguru Wetlands, is a natural lake, with an area of about 58,100 hectares and depth of between $1.5 \mathrm{~m}$ to $7 \mathrm{~m}$. Of all the physico-chemical parameters studied only temperature, $\mathrm{pH}$ and sulphate concentration showed significant seasonal variation $(\mathrm{P}<0.001)$. However all the physico-chemical parameters exhibited highly significant spatial variations $(\mathrm{p}<0.001)$. The concentration of metals was in the following order $\mathrm{Mn}>\mathrm{Zn}>\mathrm{Fe}>\mathrm{Ca}>\mathrm{Mg}>\mathrm{Cu}$. Pearson's product moment correlation coefficient between conductivity and other physical properties of the lake indicated a highly positive significant correlation. The zooplankton of Nguru Lake was made up of four groups, Cladocera (41\%), Copepoda (24\%), Rotifera (27\%) and Protozoa (18\%). There was a total of 16 species with Moina and Keratella dominating the fauna. The zooplankton showed significant seasonal and spatial variation $(\mathrm{P}<0.001)$. The lake is gradually tending towards eutrophication.
\end{abstract}

Keywords: Limnology, Nguru Lake, Variation, Wetlands, Zooplankton

\section{Introduction}

In the last two decades, there has been a growing necessity for conservation of our resources, especially water. At the same time, growing populations, progressive industrialization and intensification of agriculture have led to increased pollution of surface waters. This induces ecological imbalances, deleterious for sustained development of fisheries resources, which has necessitated the suspension of the beneficial uses of these water bodies in some places [1].

Nevertheless, an increasing number of specially created environmental agencies are being assigned the task of conserving water quality for all uses within one river or lake basin. In conserving water quality for multipurpose use, a holistic approach was recommended [2] in which all-immediate and potential interests in the water basin are considered simultaneously. Experience has shown that only an ecologically healthy fresh water ecosystem fulfils this goal and the ecology of the flora and fauna of the ecosystem best measure this. Water quality monitoring is of immense importance in the conservation of water resources for fisheries, water supply and other activities; it involves the assessment of physico-chemical parameters of water bodies. Impacted changes in the quality of water are reflected in the biotic community structure, with the vulnerable dying, while the most sensitive species act as indicators of water quality [3]. Several studies on aquatic ecosystem impairment have been reported in Nigerian water bodies. These include the works of $[4,5$, and 6$]$.

Nguru Lake being an important internationally recognized ecological site, this study is aimed at providing useful inputs and experience necessary for the management of the environmental aspects of the many multi-purpose lakes and reservoirs in the semi-arid zones of Nigeria for fisheries especially.

This study is necessary to update the information and determine the effects of anthropogenic activities on water quality characteristics and nutrient level in relation to zooplankton abundance of the lake. 


\section{Materials and methods}

The procedure of this study involved monthly collection of samples for all the physico-chemical parameters and zooplankton in five sampling sites (fig. 1) using standard methods.

\subsection{Sampling sites}

Based on the results of the preliminary study five sampling sites were selected on the lake for the purpose of sample collection. These sampling sites are:

Site 1:-Punjamu is located at the entry to the lake were water drains from the Marma channel between coordinates N12 49' 16.1" and E10 24' 21.5"with an altitude of 343m. The flow of water current is strong here as such the place is devoid of aquatic macrophytes. There is not much of human activity at this point.

Site 2:-Badun is located close to Dabar Magini settlement, between coordinates N12 50' 27.9" and E10 24' 08.1" with an altitude of $334 \mathrm{~m}$. A lot of fishing and agricultural activity is taking place here. In addition, the people of this settlement are engaged in the exploration and refining of potash.

Site 3:- This is a midlake region where human activity is minimal. However, this site has a thick growth of aquatic macrophytes predominantly Typha $s p$. The depth of this site ranges from $0.5 \mathrm{~m}-1.5 \mathrm{~m}$. This site is located between coordinates N12 49' 40.7" and E10 24' 21.1" with an altitude of 341m above sea level.

Site 4:-Garbi is located between coordinates N12 49' 40.7" and E10 24' 21.1" with an altitude of 330m above sea level. This is located close to a large settlement of fishermen and a railway station. A lot of human activity is taking place here. People come to wash their clothes, take bath, swim for leisure and do other activities.

Site 5:-Army barracks is the shallowest part of the lake. This site is located between coordinates N12 52' 04.8" and E10 27 ' 45.2" with an altitude of $340 \mathrm{~m}$ above sea level. This site is mostly used for livestock feeding and irrigation farming. The water in this site recedes during the dry season. The average depth here is less than $1 \mathrm{~m}$. Most of the wastewater from Nguru town drains unto this site.

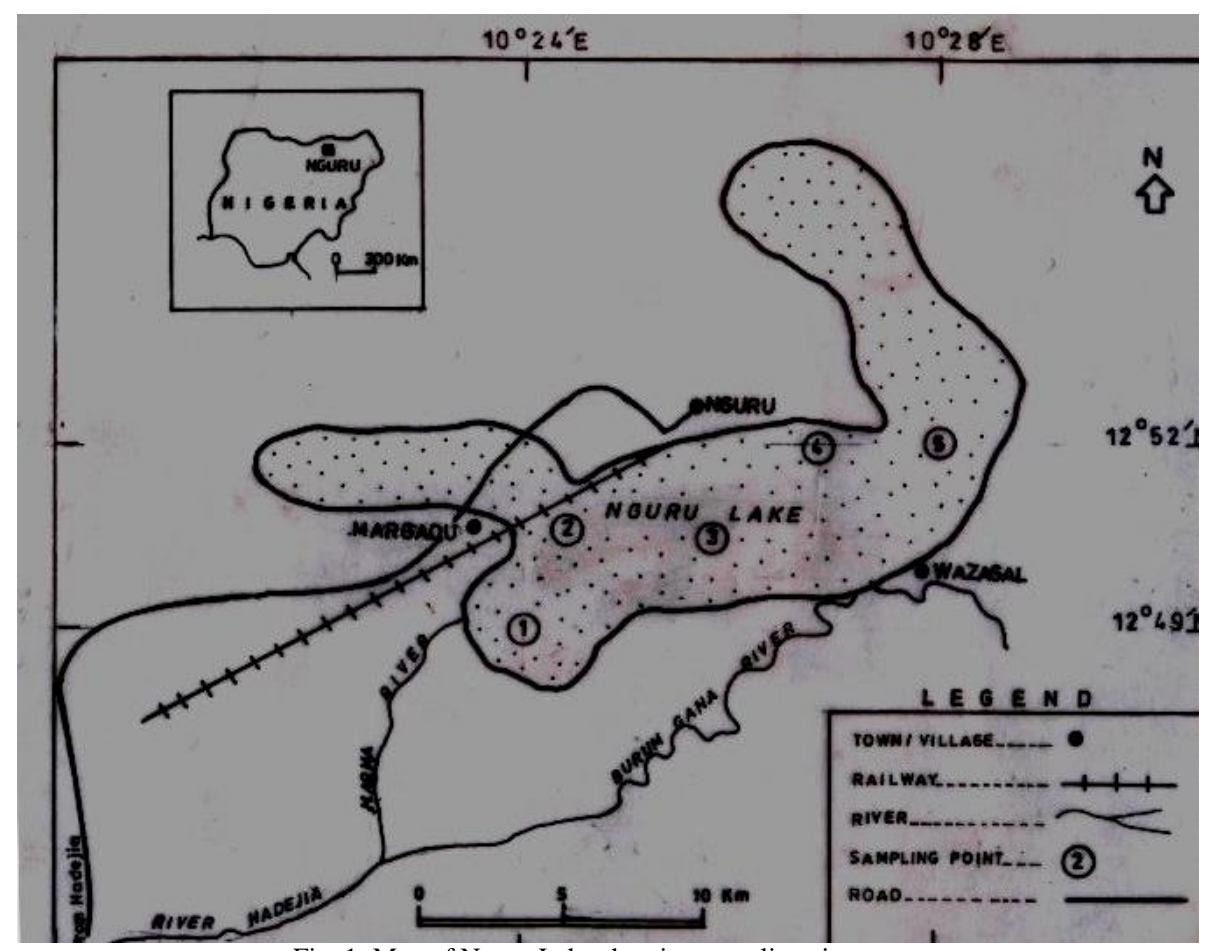

Fig. 1: Map of Nguru Lake showing sampling sites

\subsection{Determination of physico-chemical parameters}

Temperature and $\mathrm{pH}$ were determined in the field using $\mathrm{pH}$ meter, Model 3150. Other physico-chemical parameters were determined in the laboratory with Hach 2010 spectrophotometer using the methods of [7]. 


\subsection{Sampling and identification of Zooplankton}

Samples of zooplankton are collected using plankton net of mesh size $100 \mathrm{~nm}$. The net is tied to a metal rod, and immersed into the water, towed for a fixed distance, and hauled out of the water. The water (containing plankton) that is collected in the plastic bottle at the end of the net is emptied into sample bottles and preserved with 4\% formation, [8]. The zooplankton was indentified using keys in [9]. Enumeration of the plankton was done with the method of [10].

\subsection{Data analysis}

The seasonal data was analyzed by one-way analysis of variance (ANOVA), Duncan's multiple range tests (DMRT) was used to compare the means and Pearson's product moment correlation coefficient was used to determine association between the physico-chemical properties and the zooplankton.

\section{Results}

The results of physico-chemical parameters are presented in table1. Of all the physico-chemical parameters studied only temperature, $\mathrm{pH}$, total dissolved solutes, dissolved oxygen and sulphate concentration showed significant seasonal variation $(\mathrm{P}<0.001)$. However all the physico-chemical parameters exhibited highly significant spatial variations $(\mathrm{p}<0.001)$. The concentration of metals was in the following order $\mathrm{Mn}>\mathrm{Zn}>\mathrm{Fe}>\mathrm{Ca}>\mathrm{Mg}>\mathrm{Cu}$. Pearson's product moment correlation coefficient between conductivity and other physical properties of the lake indicated a highly positive significant correlation $(>0.718)$.

Table 1- Mean spatial distribution of physico-chemical parameters of Nguru Lake.

\begin{tabular}{lllllll}
\hline Parameter & Station 1 & Station 2 & Station 3 & Station 4 & Station 5 & Mean \\
\hline Temperature & $16.25 \mathrm{~b}$ & $20.29 \mathrm{a}$ & $17.63 \mathrm{~b}$ & $21.71 \mathrm{a}$ & $20.92 \mathrm{a}$ & 19.36 \\
pH & $8.77 \mathrm{a}$ & $8.59 \mathrm{~b}$ & $8.16 \mathrm{c}$ & $7.87 \mathrm{~d}$ & $8.29 \mathrm{a}$ & 8.33 \\
Transparency & $91.46 \mathrm{~b}$ & $137.67 \mathrm{a}$ & $42.55 \mathrm{c}$ & $17.67 \mathrm{~d}$ & $19.83 \mathrm{~d}$ & 103.06 \\
Depth & $178.8 \mathrm{a}$ & $188.08 \mathrm{a}$ & $54.29 \mathrm{~b}$ & $52.16 \mathrm{~b}$ & $49.87 \mathrm{~b}$ & 104.64 \\
TDS & $74.17 \mathrm{c}$ & $61.75 \mathrm{~d}$ & $90.08 \mathrm{~b}$ & $97.21 \mathrm{a}$ & $92.25 \mathrm{ba}$ & 83.09 \\
Suspended solids & $2.04 \mathrm{~d}$ & $3.38 \mathrm{c}$ & $3.25 \mathrm{c}$ & $6.00 \mathrm{a}$ & $5.00 \mathrm{~b}$ & 3.93 \\
Turbidity & $2.50 \mathrm{~d}$ & $4.17 \mathrm{c}$ & $6.75 \mathrm{~b}$ & $12.63 \mathrm{a}$ & $6.46 \mathrm{~b}$ & 6.49 \\
Conductivity & $171.25 \mathrm{~b}$ & $122.77 \mathrm{c}$ & $180.68 \mathrm{~b}$ & $203.38 \mathrm{a}$ & $182.76 \mathrm{~b}$ & 172.16 \\
Alkalinity & $30.54 \mathrm{~b}$ & $35,67 \mathrm{a}$ & $25.75 \mathrm{~b}$ & $23.38 \mathrm{a}$ & $18.27 \mathrm{~b}$ & 26.72 \\
DO & $7.64 \mathrm{a}$ & $7.09 \mathrm{~b}$ & $6.39 \mathrm{c}$ & $6.25 \mathrm{c}$ & $6.37 \mathrm{c}$ & 6.74 \\
BOD & $2.26 \mathrm{~d}$ & $1.98 \mathrm{~d}$ & $9.40 \mathrm{a}$ & $4.09 \mathrm{c}$ & $5.44 \mathrm{~b}$ & 4.63 \\
COD & $6.42 \mathrm{dc}$ & $5.73 \mathrm{~d}$ & $7.73 \mathrm{c}$ & $11.48 \mathrm{~b}$ & $15.24 \mathrm{a}$ & 9.32 \\
Total Phosphate & $5.93 \mathrm{~b}$ & $5.12 \mathrm{~b}$ & $5.74 \mathrm{~b}$ & $5.93 \mathrm{~b}$ & $11.56 \mathrm{a}$ & 6.86 \\
Total Nitrogen & $5.37 \mathrm{c}$ & $6.03 \mathrm{a}$ & $5.45 \mathrm{a}$ & $6.23 \mathrm{a}$ & $6.32 \mathrm{a}$ & 5.88 \\
Sulphate & $3.29 \mathrm{c}$ & $5.01 \mathrm{~b}$ & $4.79 \mathrm{~b}$ & $6.04 \mathrm{a}$ & $5.84 \mathrm{a}$ & 4.99 \\
Magnesium & $0.07 \mathrm{bc}$ & $0.05 \mathrm{c}$ & $0.11 \mathrm{a}$ & $0.09 \mathrm{ba}$ & $0.08 \mathrm{bc}$ & 0.08 \\
Calcium & $0.63 \mathrm{~d}$ & $0.15 \mathrm{c}$ & $0.19 \mathrm{c}$ & $0.34 \mathrm{a}$ & $0.16 \mathrm{c}$ & 0.29 \\
Iron & $0.11 \mathrm{~d}$ & $0.15 \mathrm{c}$ & $0.27 \mathrm{~b}$ & $0.30 \mathrm{a}$ & $0.31 \mathrm{a}$ & 0.23 \\
Zinc & $0.59 \mathrm{~b}$ & $0.91 \mathrm{a}$ & $0.78 \mathrm{ba}$ & $0.85 \mathrm{a}$ & $0.56 \mathrm{~b}$ & 0.74 \\
Copper & $0.01 \mathrm{~d}$ & $0.14 \mathrm{a}$ & $0.01 \mathrm{~d}$ & $0.07 \mathrm{c}$ & $0.11 \mathrm{~b}$ & 0.07 \\
Manganese & $2.17 \mathrm{~d}$ & $3.06 \mathrm{c}$ & $4.80 \mathrm{~b}$ & $5.15 \mathrm{~b}$ & $6.54 \mathrm{~b}$ & 4.34 \\
\hline
\end{tabular}

Means with the same letter in the same column are not significantly different using DMRT.

Results of zooplankton are presented in table 2. The zooplankton of Nguru Lake was made up of four groups, Cladocera (41\%), Copepoda (24\%), Rotifera (27\%) and Protozoa (18\%). There was a total of 16 species with Moina and Keratella dominating the fauna. The zooplankton showed significant seasonal and spatial variation $(\mathrm{P}<0.001)$. Shannon-Weiner index of 5.76, 4.14 and 5.02 for stations 1,2 and 3 respectively indicate that these stations have relatively high species diversity and therefore are not polluted. But stations 4 and 5 with indexes of 2.96 and 1.98 respectively have relatively lower species diversity suggesting possible pollution. 
Table 2. Mean distribution of Zooplankton in Nguru Lake and the diversity indices of the stations.

\begin{tabular}{|c|c|c|c|c|c|c|}
\hline Cladocera & Site 1 & Site 2 & Site 3 & Site 4 & Site 5 & Total \\
\hline Moina micrura Kutz & 111 & 212 & 31 & 41 & 12 & 407 \\
\hline Ceriodaphnia cornuta Sars & 91 & 230 & 52 & 81 & 22 & 476 \\
\hline Simocephalus serrulatus Koch & 82 & 171 & - & 41 & - & 294 \\
\hline Gurnayella mondi Sars & 72 & 111 & - & - & - & 183 \\
\hline Monella excisa Kutz & - & 81 & - & - & - & 81 \\
\hline Alona monacantha Sars & - & 72 & 21 & - & - & 93 \\
\hline \multicolumn{7}{|l|}{ Copepoda } \\
\hline Tropodiaptomus incognitos $\boldsymbol{D} \& \boldsymbol{G}$ & - & 51 & 12 & - & - & 63 \\
\hline Thermocyclops neglectus Sars & 112 & 101 & - & - & - & 213 \\
\hline Macrocyclops albidus Imhof & 131 & - & - & - & - & 131 \\
\hline Afrocyclops gibsoni Kutz & 72 & 101 & - & 73 & - & 246 \\
\hline \multicolumn{7}{|l|}{ Rotifera } \\
\hline Brachionus patulus Muller & 91 & 172 & 71 & 82 & 33 & 449 \\
\hline Keratella quadrata Hauer. & 141 & 192 & 42 & 103 & 31 & 509 \\
\hline Kellicottia longispina Kellicott & 22 & 41 & - & - & - & 63 \\
\hline \multicolumn{7}{|l|}{ Protozoa } \\
\hline Paramecium sp. & - & - & 32 & 11 & 10 & 53 \\
\hline Colpidium campylum Sars & - & - & - & 51 & 22 & 73 \\
\hline Mean No. of individuals(N) & 911 & 1362 & 253 & 561 & 20 & 621.4 \\
\hline No. of species (S) & 10 & 12 & 7 & 8 & 6 & 43 \\
\hline Shannon-Weiner index(D) & 5.76 & 4.14 & 5.02 & 2.96 & 1.98 & 3.97 \\
\hline Evenness index(E) & 0.96 & 0.906 & 0.944 & 0.66 & 0.50 & 0.794 \\
\hline
\end{tabular}

\section{Discussion}

The extreme ecological conditions of the Sahel savanna especially climatic variation could have a resultant effect in modifying lake ecosystems. The water regime in this lake was mainly influenced by rainfall pattern and duration, in addition to discharge from its tributaries. So it is expected that any variation, whether seasonal or spatial in physicochemical properties of Nguru lake may be influenced by climatic regime and catchments characteristics i.e. extent of human activities, and water volume fluctuations.

This could have resulted in the significant seasonal and spatial variation in temperature, dissolved oxygen, $\mathrm{pH}$, and sulphate during the study period. Studies by [11] showed that temperature variation in lakes might be caused by the influence of environmental factors and human activities in or around the lake. Dissolved oxygen(DO) provides a broad indicator of water quality and that DO concentrations in unpolluted waters are normally about $8-10 \mathrm{mgl}^{-1}$ (at $25^{0} \mathrm{c}$ ). The DO range of 4.9 to $9.1 \mathrm{mgl}^{-1}$ in Nguru Lake was similar with the range of $5 . \mathrm{mgl}^{-1}$ to $8.9 \mathrm{mgl}^{-1}$ observed by [12] at Lake Volta. This result indicates that the lake is tending towards eutrophication. The concentration of nutrients in a water body is strongly influenced by the nature of the sediment. Wetzel [13], states that the rate of phosphorus release into the water can double, when sediments are frequently disturbed. The phosphate level in Nguru Lake may be a result of release from disturbed sediment and anoxic conditions as a result of decaying macrophytes. The values of metals observed at Nguru Lake were generally lower than the values reported for other African lakes [14, 15].

Sixteen species of zooplankton were recorded during the study period, of which members of the Cladocera dominated with seven species, constituting $38 \%$ of the total population observed. This observation is similar with the findings of [16] who reported that the zooplankton community of Hadejia-Nguru wetlands was characteristic of Sudano-Sahel fauna. The richness of Cladocera in Nguru Lake was relatively high; this may be attributed to the abundance of aquatic macrophytes, particularly Typha in the water, which hampers the rate of predation by fish. As Sarnelle [17] suggested that fish prefer open waters to feed on zooplankton. This was further collaborated by [18, 19 and 20] who observed that the absence of Cladocera and the low numbers of Copepoda could be due to the effects of fish predation, which was found to be the major factor structuring zooplankton assemblages in several studies. Work on some lakes by [21] indicates that the degree of vegetation affects zooplankton distribution with the greatest number of zooplanktonic organisms in waters with sparse vegetation.

The Cladocera was the dominant zooplankton in Nguru Lake, both in terms of species diversity and in terms of biomass. However, what was remarkable was that the Rotifera with only two species was the second highest in terms of biomass. This may most likely be due to the increasing importance of Cyanophyta in Nguru Lake. This view was supported by the findings of [22] who reported the dominance of rotifers in lake Linhas, Portugal. They attributed this to the fact that 
the rotifers are abundant in water bodies with a wide range of physico-chemical conditions and that they are able to use bacteria, cyanophytes and suspended detritus as food resources.

\section{Conclusion}

From the results of the studies conducted, one can safely conclude that. Different levels of anthropogenic inputs have caused wide variations in physico-chemical parameters in the various parts of Nguru Lake.There was significant seasonal and spatial variation in physico-chemical parameters. Human activities and other biotic factors were implicated as the reasons for the observed spatial variations in the distribution of zooplankton of the lake.

\section{Recommendations}

1. Experimental research should be undertaken at Nguru Lake, specifically on the control of Typha, study of predation among the biota and the effect of siltation on the ecosystem of the lake.

2. There should be additional support for research in key areas of aquatic biology. This will generate new fundamental knowledge and advanced technologies for developing and improving bioremediation, cultivation of aquatic species and expanding biological processes in aquatic ecosystem and their role in global change.

3. The application of agro-climatic and limnological researches carried out in our universities and research institutes to solve day-to-day problems like eutrophication should be encouraged.

\section{References}

[1] A.H. Kawo, Laboratory investigation on the effect of some physical and chemical factors on the total microbial population in relation to eutrophication and purification of Salanta River, Kano, (unpublished) M.Sc. thesis Bayero university Kano, Nigeria. (1996) 22.

[2] UNEP, Chemical pollution. A global overview. United Nations Environment Program. UNEP. Geneva (1985).

[3] M.T. Barbour, J. Gerristen, B.D. Synder, and J.B. Stribbling, Rapid Bioassessment protocols for use in streams and wadeable rivers. Periphyton, Benthic Macroinvertebrates and Fish, Second edition EPA 842-B-99-002 USEPA,office of water, Washington D.C. (1999).

[4] S.S Ogbogu, and A.T. Hassan, Effects of sewage on physico-chemical variables and Ephemeroptera (Mayfly) larvae of a stream reservoir. Journal of Aquatic Sciences. 11 (1996) 43-55.

[5] B.O. Oben, Limnological assessment of the impact of agricultural and domestic effluents of three man-made lakes in Ibadan, Nigeria. (unpublished) Ph.D. thesis, university of Ibadan (2000).

[6] S.S. Ogbogu, Fundamentals of Ecology, W.B. Saunders Ltd. Philadelphia, USA (2001) 610.

[7] APHA, Standard methods for examination of waters and wastewaters, 20th ed. American public health authority, Washington D.C. USA 2112 (1998).

[8] R.G. Wetzel, and G.E. Likens, Limnological Analysis, W.B. Saunders Philadelphia USA (1979) 357.

[9] C.Y. Jeje, and C.K. Fernando, A practical guide to the identification of Nigeria Zooplankton, Kainji Lake Institute Nigeria (1986).

[10] C.E. Boyd, Water quality in warm water fish ponds agricultural experimental station. Gaftmaster pub. Co. Alabama USA (1981) 359.

[11] J.W. Wade, Limnology and trace element studies. In relation to primary production in two mine lakes Unpublished M.Sc thesis, university of Jos Nigeria (1985) 205.

[12] A.Y. Karikari, J.K. Bernasko, and E. K. A. Bosque - Hamilton, An assessment of water quality of Angaw - River in South - eastern coastal plains of Ghana, West African Journal of Applied Ecology, Vol. II (1) (2007) 33 - 46.

[13] R.G. Wetzel, Limnology, Lake and River ecosystems (3rd edn) Academic Press. San Francisco USA (2001).

[14] S.V. Matagi, D. Swai, and R. Mugabe, A review of heavy metal removal mechanisms in wetlands. African Journal of Tropical Hydrobiology and Fisheries 8 (1998) 23-35.

[15] F.W. B. Bugenyi, and A. J. Lutalo-Bosa, Likely effects of salinity on copper toxicity to the fishes of Lake George Edward basin in, P. Kilham and K. M. Mavuh (Eds). Comparative ecology of fresh water and coastal marine ecosystems. Hydrobiologia 208 (1990) $38-44$.

[16] B. A. Abdullahi, Hydrobiology component. Biodiversity study of the aquatic fauna and flora of the Hadejia-Nguru wetlands, Hadejia-Nguru Wetlands Conservation Project. (HNWCP), Nguru, Nigeria (1997) 79-86.

[17] O. Sarnelle, Nutrient enrichment and grazer effect on phytoplankton in lakes, Ecology 73 (1992) $551-556$.

[18] E.C. Kemdirim, Diel Rhythm of plankton and physio-chemical parameters in Kangimi reservoir, Kaduna state, Journal of Aquatic Science, 15(1) (2000) 35-39.

[19] E. Jeppessen, J. Jensen, H. Skovgaard, and L. Havidt, Change in the abundance of planktivorous fish in lake Skanderborg during the past two centuries- palaeoecological approach, Paleogeography, Paleoclimatology, Paleoecology 172 (2001) 143-152.

[20] K. E. Havens, Zooplankton structure and potential food web interactions in the plankton of a subtropical chain of lakes, Scientific World 8 (2002) $926-942$.

[21] L. Hakanson, and V. Boulion, Modelling production and biomasses of herbivorous and predatory Zooplankton in lakes, Ecological Modelling 161 (2003) 1-3.

[22] R. Pereira, A. Soares, R. Ribeiro, and F. Calves, Assessing the trophic State of Linhos lake, a first step towards ecological rehabilitation, Environmental Management 61 (2002) 285- 297. 